s. Mariola Małgorzata M. Michalak ${ }^{1}$

Katolicki Uniwersytet Lubelski

\title{
Siostra Klara Staszczak (1905-1991) jako przykład heroicznej realizacji konsekracji zakonnej
}

Zakon św. Benedykta w swej piętnastowiecznej historii wydał wielu świętych, kanonizowanych i beatyfikowanych, którzy stanowią o jego duchowym bogactwie. Wśród ludzi kroczących drogą Ewangelii, ukazaną w Regule benedyktyńskiej, jest wielu cichych świadków wąskiej drogi prowadzącej do królestwa niebieskiego. Takim darem Bożej łaski wydaje się życie s. Klary Staszczak, benedyktynki misjonarki, dla której nie było nic droższego od Chrystusa. Jej postać jest znana w zgromadzeniu, jednak brak pogłębionego studium, a także opracowań krytycznych życia i misji s. Marii Klary, dokonanych w oparciu o materiały źródłowe. Powstały prace magisterskie, w których pojawiają się wzmianki na jej temat, ale nie ma opracowań monograficznych. Niniejszy artykuł nie rości sobie praw do wyczerpania i rzetelnego opracowania tematu - stanowi niewielki przyczynek do dalszych wnikliwych badań nad życiem i działalnością tej niezwykłej osoby.

1 S. mgr lic. Mariola Małgorzata Michalak - benedyktynka misjonarka, doktorantka w Instytucie Teologii Duchowości Katolickiego Uniwersytetu Lubelskiego. 
Opracowanie jest głównie wynikiem pracy nad wybranymi materiałami źródłowymi przechowywanymi w archiwum zgromadzenia w Otwocku. Wyłania się z nich postać prostej dziewczyny, później siostry benedyktynki misjonarki, której życie jawi się jako szczególny przykład wielkiej miłości do Boga i Kościoła. Siostra Klara szczególnie umiłowała Kresy Wschodnie, którym oddała całe swe serce. Aby zrozumieć heroizm jej życia monastycznego niejako „od wewnątrz”, trzeba prześledzić historię jej życia, poznać środowisko i warunki, w jakich kształtowały się jej charakter i życie wiary.

W związku z tym w pierwszym punkcie przyjrzymy się drodze Klementyny Staszczak, późniejszej s. Marii Klary, do Zgromadzenia Sióstr Benedyktynek Misjonarek. W drugim punkcie ukazana zostanie sylwetka duchowa, natomiast przedmiotem trzeciego będzie heroizm oddania w konsekracji zakonnej. Realizację ślubów zakonnych będziemy rozumieć jako doświadczenie obecności Boga. W życiu s. Klary był to stan życia duchowego, w którym dusza ludzka będąca w stanie łaski uświęcającej, a więc oczyszczona z grzechów i złych skłonności, bezpośrednio doświadcza łączności z Bogiem, które to przeżycie jest darem udzielonym przez Niego samego ${ }^{2}$.

\section{Droga Klementyny Staszczak do zgromadzenia}

\subsection{Dom rodzinny}

Droga Klementyny do zgromadzenia zakonnego rozpoczęła się w domu rodzinnym, później zaś kontynuowana była na drodze rad ewangelicznych.

Dom rodzinny często kojarzy się z miejscem, gdzie wpajane są dobre obyczaje i kształtowana jest wiara i wartości, dzięki którym można podejmować odpowiedzialne decyzje w dorosłym życiu. Szczęśliwi są ci, którzy mieli dom, do którego wracają sercem i myślą, by coraz lepiej pojmować

2 Por. J. Misiurek, Modlitwa, medytacja, kontemplacja, mistyka, Dzieje problematyki, Lublin 2011, s. 305. 
wagę tego daru. Taki był rodzinny dom Klementyny Staszczak. Jej rodzina żyła na Wołyniu3. To tam, w Żdżarach, 6 listopada 1905 roku przyszła na świat Klementyna. Została ochrzczona w kościele parafialnym św. Michała Archanioła w Litowiżu. Od początku doświadczała w rodzinnym domu poczucia bezpieczeństwa, miłości i wzajemnej życzliwości. Jej ojciec, Paweł Staszczak, pracował na kolei przy budowie mostów, natomiast matka Stanisława Staszczak (z domu Abramowicz) zajmowała się prowadzeniem domu oraz wychowywaniem czwórki dzieci: trzech córek i syna. Podstawowym źródłem ich utrzymania była uprawa roli. Klementyna miała zapewnione wszelkie warunki, by swobodnie i bez przeszkód rozwijać się intelektualnie i duchowo. Dom zajmował w pamięci s. Klary szczególne miejsce, był swoistą oazą pokoju i miłości. Świadczą o tym jej własne słowa: „Będąc dzieckiem, nigdy w domu nie słyszałam kłótni ani przekleństw"4.

Rodzinny dom przypominał s. Klarze rodzinne szczęście, dzieciństwo i młodość, choć przyszło Jej żyć w niełatwej sytuacji i trudnych uwarunkowaniach historycznych. Stworzenie prawdziwego domu przez ojca Klementyny było bardzo ważne w procesie wychowania osieroconych przez wczesną śmierć matki dzieci. To właśnie tam rozwijał się i formował charakter s. Klary, tam uczyła się otaczającego Ją świata. Z rodzinnego domu wyniosła mądrość, odwagę i rozwagę, która pozwalała Jej zawsze iść za głosem serca. Sama również wpajała później swoim wychowankom mądrość, prawość, a przede wszystkim wartości ewangeliczne: wiarę, nadzieję i miłość. Dom rodzinny odegrał w życiu s. Klary doniosłą rolę. Świadczą o tym również jej słowa: „Pierwsze Boże Narodzenie poza domem rodzinnym pozostawiło w mej duszy smutne wspomnienie. Była choinka, opłatek, wspólna wieczerza tylko dla dzieci. Siostry razem z nami nie jadły. W ten święty wieczór odczułam swoje sieroctwo (gdyż

3 Wołyń obejmuje obwody wołyński i rówieński, zachodnią część żytomierskiego oraz północne części tarnopolskiego i chmielnickiego na Ukrainie.

4 Życiorys Klementyny Klary Staszczak OSB, w: Dokumenty, życiorysy, podróże, Listy s. Klary, Archiwum Sióstr Benedyktynek Misjonarek w Otwocku [dalej: ABMO], rkps, tk. P 12/1. 
już matki nie miałam) i pomyślałam sobie, że gdy zostanę zakonnicą, to wieczerzę wigilijną będę spożywać razem z dziećmi" ${ }^{5}$.

Powołaniem każdej rodziny i wyzwaniem stojącym przed nią było ciągłe dawanie świadectwa o wspólnocie jako miejscu, gdzie panują miłość, wierność, umiłowanie prawdy, przebaczenie, solidarność, w której domownicy nie tylko nie tracą swej tożsamości, ale - jak podkreślał święty Jan Paweł II - „wnosząc własne, szczególne dary, przyczyniają się do wzrostu wszystkich"6.

Pawłowi Staszczakowi nie był obojętny los dzieci, choć sam przeżywał utratę ukochanej osoby, jaką była jego żona i matka ich dzieci. Uczył swoje dzieci, że nie można zamykać się w doświadczeniu własnego bólu. Być może w tym też należy upatrywać źródła późniejszego zatroskania s. Klary o tych najbardziej potrzebujących: dzieci i ludzi dotkniętych cierpieniem. Człowiek sam nie potrafi kochać doskonale, dlatego musi swoją miłość zanurzyć w miłości Boga, w Tym, który je st Miłością. Miłość otworzyła wnętrze s. Klary, napełniła jej życie treścią, ubogaciła i pozwoliła z rzeczy zwykłych czynić niezwykłe. Tylko miłość ma moc przekształcać zwykły dzień w święto, a życie uczynić wielką przygodą świętości.

\subsection{Powołanie}

15 sierpnia 1921 roku to szczególny moment odczytania przez Klementynę Bożego wezwania do wyłącznej służby Bogu i ludziom. Była to pierwsza rocznica cudu nad Wisłą, a w życiu Klementyny doświadczenie cudu łaski powołania. „Będąc na polowej Mszy świętej w roku 1921, uczułam chęć jakiegoś unicestwienia się, zaparcia się, życia w ukryciu z Bogiem"'. Cechą wyróżniającą mistykę bez wątpienia jest tajemnicze działanie Boga w duszy ludzkiej. Bóg rozpłomienia osobę swoim światłem i miłością, a osoba dotknięta tym płomieniem zdaje sobie z tego

5 A. Jagłowski, Historia Zgromadzenia Sióstr Misjonarek św. O. Benedykta, Olsztyn 1955, ABMO, mps, s. 68-69.

6 Jan Paweł II, Wielki Jubileusz wezwaniem dla rodzin. Katecheza środowa, 29.12.1999, http://www.opoka.org.pl/biblioteka/W/WP/jan_pawel_ii/audiencje/ag_29121999.html.

A. Jagłowski, Historia Zgromadzenia..., dz. cyt., s. 68. 
sprawę i jest świadoma wagi tego oddziaływania․ Tak było w przypadku Klementyny. Odczuła doskonale ten „Boży dotyk” łaski i chciała na niego odpowiedzieć. Był to więc jakiś rodzaj mistycznego doświadczenia, które w sposób radykalny wpłynęło na dalsze jej życie9. Pozornie przypadkowe zdarzenie stało się osobistym zwróceniem się Boga do młodej dziewczyny. Wyczuła wewnętrzne przynaglenie do tego, co Pan chciał, by uczyniła. Warunkiem sztuki odbioru natchnień Ducha Świętego jest postawa gotowości i otwarcia, a to początkowo nie przychodziło Klementynie łatwo. Była przekonana, że życie w zakonie jest tylko dla szczególnie wybranych, a ona jest tego niegodna, chciała więc jedynie służyć swoją pomocą siostrom. W jej wyobrażeniu nastolatki siostry zakonne były osobami świętymi, sama czuła się niegodna dostąpienia tak wielkiego daru. od początku rozumiała, że Bóg jest Miłością, a naśladowanie Jego to nic innego jak świętość, to uczenie się Jego miłości bezinteresownej, a jednocześnie mądrej. Sama nie czuła się godna podjęcia takiej misji. Zgłosiła się do benedyktynek w Kowlu z myślą o wykonywaniu prostych posług w zgromadzeniu. Jednak po kilku miesiącach, w czasie których pomagała siostrom w ich pracach, odważyła się poprosić o przyjęcie do wspólnoty sióstr. Myśl o zakonie nie dawała jej spokoju. Modliła się więc gorliwie do św. Benedykta, by przyjął ją w poczet swoich duchowych córek. Jej modlitwa przeradzała się w coraz bardziej gorące i żarliwe wołanie i błaganie. Poczuła, że życie tej wspólnoty, proste i radosne, pociągało ją do takiego samego stylu życia, dla Boga i Kościoła. W tym czasie przełożoną generalną była m. Gerarda Apolonia Sokołowska ${ }^{10}$. Można przypuszczać, że Matka Gerarda wyszła też naprzeciw tym pragnieniom i zapytała

8 Por. J. W. Gogola, Teologia komunii z Bogiem, Kraków 2003, s. 383.

9 Zob. M. Wolska, Zaangażowanie Sióstr Benedyktynek Misjonarek na rzecz Kościoła Katolickiego na Ukrainie, Referat wygłoszony 21.10.2005r. w Bibliotece Głównej KUL podczas dwudniowej Międzynarodowej Sesji Naukowej nt. Zaangażowanie duchowieństwa polskiego na rzecz Kościoła katolickiego na Wschodzie (Ukraina). Sesja zorganizowana przez ks. dr Józefa Szymańskiego odbyła się w dniach 21-22.10.2005. Materiał pochodzi ze zbiorów własnych autorki.

10 Maria Gerarda Apolonia Sokołowska OSB (1893-1979) została pierwszą po założycielce przełożoną generalną. Urząd swój sprawowała od 1921 do 1929 roku (sama się go zrzekła, dlatego w tym roku odbyła się nadzwyczajna kapituła generalna, na której wybrano nową przełożoną generalną, m. Marię Małgorzatę Szyndler. Matka Gerarda została mistrzynią nowicjatu. 
wprost, czy nie chciałaby zostać siostrą zakonną. Wówczas Klementyna uklękła i poprosiła o przyjęcie ${ }^{11}$. Początkowo przełożona zgodziła się przyjąć Klementynę, lecz jako wychowankę, ponieważ była bardzo mło$\mathrm{da}^{12}$. Nie miała jeszcze skończonych siedemnastu lat i potrzebne było otrzymanie zgody ojca. Błogosławieństwo ojcowskie było obficie zroszone łzami, lecz w końcu je otrzymała. W ulewny deszcz, zabierając ze sobą wiszący na ścianie obraz serca Jezusowego, poszła do klasztoru odległego 6 km od jej domu ${ }^{13} .20$ kwietnia 1922 roku matka Gerarda przyjęła ją do postulatu. Biskup Dubowski ${ }^{14}$, obecny podczas ceremonii przyjęcia do postulatu, pytał każdą postulantkę o wolę służenia Panu Bogu. Po otrzymaniu pasterskiego błogosławieństwa znikł wszelki niepokój w sercu Klementyny i zagościła w nim pewność wybrania i powołania. Od tego dnia była pewna, że chce ofiarować swoje życie w tej wspólnocie zakonnej. Wielką radością dla rozpoczynającej drogę życia zakonnego było założenie na głowę czarnego weloniku podszytego białym płótnem i codzienne wzywanie na poranne i wieczorne modlitwy. Uczyła się wszystkiego: modlitwy, rozpoznawania działania Bożego, życia we wspólnocie: piękna i jego trudu. W przypadku Klementyny podjęcie powołania zakonnego było decyzją wiary i zawierzenia, bo czuła, że nie żyje tylko dla siebie. Chciała oddać się całkowicie Bogu. Po kilku miesiącach, 15 sierpnia, Klementyna została dopuszczona do nowicjatu. Głęboko przeżyła czas pierwszych zakonnych rekolekcji. Prowadził je ks. Antoni Jagłowski ${ }^{15}$. Zdarzyło się, że w czasie ich trwania do klasztoru przyjechała pani Malicka, rodzona siostra s. Stanisławy Rymarz, z dwiema córeczkami,

11 Por. A. Jagłowski, Historia Zgromadzenia..., dz.cyt., s. 69.

12 Błogosławieni, którzy umierają w Panu, dz. cyt., s. 216.

13 Zob. Życiorys Klementyny Klary Staszczak OSB, dok. cyt., ABMO, rkps, tk. P 12/1.

14 Abp Ignacy Dub-Dubowski, ordynariusz diecezji łucko-żytomierskiej. Święcenia kapłańskie otrzymał w 1899 roku. W październiku 1916 roku ojciec święty Benedykt XV mianował ks. Dub-Dubowskiego biskupem łucko-żytomierskim i administratorem apostolskim diecezji kamienieckiej. Sakrę biskupią otrzymał w styczniu 1917 roku w kościele św. Katarzyny w Petersburgu. Jako biskup prowadził bardzo energiczną działalność duszpasterską. W 1917 roku zatwierdził powstanie w Białej Cerkwi Zgromadzenia Sióstr Misjonarek Benedyktynek, które następnie sprowadził do Kowla. Zmarł 10.03.1953 w Rzymie.

15 Antoni Jagłowski (1891-1974); święcenia kapłańskie otrzymał w 1914 roku w Płocku; od 1917 roku pełnił posługę kapelana i opiekuna nowo powstałego Zgromadzenia Sióstr Misjonarek św. Benedykta, z którym pozostał związany aż do śmierci. 
które koniecznie chciały zerwać z drzewa dojrzałe gruszki. Te zmagania spostrzegła wrażliwa na potrzeby innych Klementyna. Nie namyślawszy się długo, weszła na strych, z niego na dach, z dachu na gruszę i zaczęła trząść drzewem, by sprawić radość dziewczynkom spadającymi owoca$\mathrm{mi}^{16}$. Widział to ks. Jagłowski i surowo pogroził kandydatce do nowicjatu. Klementyna otrzymała również napomnienie od matki Gerardy i nakaz przerwania rekolekcji. Z tym wiązała się również decyzja o niedopuszczeniu do nowicjatu. Skruszona i zawstydzona Klementyna całym sercem przepraszała za ten czyn. W końcu uzyskała przebaczenie i w kościele parafialnym została uroczyście przyjęta do nowicjatu. Uroczystościom przewodniczył ks. infułat Feliks Sznarbachowski ${ }^{17}$, a asystował ks. Jagłowski. Na pamiątkę otrzymała od ks. Jagłowskiego, którego siostry nazywały „ojcem”, obrazek z napisem: „Głęboka pokora niech będzie Twej duszy ozdobą"18. W dniu obłóczyn otrzymała imię Maria Klara i pod kierunkiem m. Gerardy Sokołowskiej, pełniącej również funkcję mistrzyni, rozpoczęła ważny etap formacji zakonnej, jakim jest nowicjat ${ }^{19}$. Ze szczerym zapałem uczyła się odkrywać tajemnicę Kościoła, powołania do życia w Kościele, w poczuciu radości, że spotkanie z Jezusem prowadzi do spotkania z drugim człowiekiem. Kochała Kościół i to, że przez chrzest stała się Jego cząstką. W zgromadzeniu znalazła autentycznych świadków wiary, którzy pomagali Jej w kroczeniu za Jezusem. Siostry, z którymi żyła, szły również drogą Kościoła, prowadzącą do życia, które się nie kończy. Do nich także należeli Ci, którzy są już na drugim brzegu: Maryja, święci i wszyscy ci, którzy przekroczyli próg śmierci. W takim otoczeniu s. Maria Klara odważnie wyruszyła w bogatą duchowo wędrówkę drogami wiary, nadziei i miłości, składając siebie w dłoniach miłującego Boga.

16 A. Jagłowski, Historia Zgromadzenia..., dz. cyt., s. 69.

17 Feliks Sznarbachowski - urodził się 29.05.1876 na Zaporożu. Czując głos Bożego powołania, ukończył seminarium duchowne w Żytomierzu i Akademię Duchowną w Petersburgu. Był wybitnym kaznodzieją i autorem rozprawy Początek rzymsko-katolickiej diec. łucko-żytomierskiej, obecnie łuckiej. Zmarł nagle 10.08.1931 w Kowlu.

18 A. Jagłowski, Historia Zgromadzenia..., dz. cyt., s. 69.

19 E. Piaścik, Zgromadzenie Sióstr Benedyktynek Misjonarek na Ukrainie w latach 1977-1991, Lublin 2008, ABMO, mps, s. 49. 


\section{Sylwetka duchowa}

Siostra Klara Staszczak pierwszą profesję złożyła 15 sierpnia 1924 roku w Kowlu. Najpierw została tam posłana do pomocy opiekuńczej przy dzieciach, następnie powierzono jej funkcję wychowawczyni dziewcząt w zakładzie. We wrześniu 1930 roku rozpoczęła kurs dla kierowników i wychowawców domów dziecka w Warszawie. Ukończyła go z bardzo dobrym świadectwem. 15 sierpnia 1931 roku złożyła śluby wieczyste w domu generalnym zgromadzenia w Łucku. Ze względu na zdolności organizacyjne i wielką gorliwość w służbie Bogu i ludziom często była wysyłana, by zakładać nowe placówki ${ }^{20}$. Złożona przez nią profesja stała się środkiem i wyrazem konsekracji życia. Był to również akt złożenia ofiary, bez której niemożliwa jest przemiana darów (analogicznie do ofiary eucharystycznej) ${ }^{21}$. Fundamentem tego stał się dla niej szczególny charyzmat naśladowania Jezusa czystego, ubogiego i posłusznego. Jako osoba konsekrowana oddała się Jemu niepodzielnym sercem (por. 1 Kor 7,34$)$.

Profesja rad ewangelicznych uczyniła ją znakiem i proroctwem dla wspólnoty sióstr i braci, z którymi się spotkała na drodze swego życia. Uważała, że ślub czystości jest wielką łaską, przez którą osoby konsekrowane zostały powołane do ściślejszego zjednoczenia z Jezusem, a przez to do uczestnictwa w tajemnicach Bożych i własnego uświęcenia dla zbawienia świata ${ }^{22}$. Siostra Klara rozumiała, że bezżenność dla królestwa niebieskiego to nie tylko rezygnacja z małżeństwa i rodziny, lecz przede wszystkim charyzmatyczny wybór Chrystusa jako wyłącznego Oblubieńca, aby z Nim dojść do najgłębszego zjednoczenia osobowego ${ }^{23}$.

„W życiu naszym codziennym rzadko odczuwamy ślub ubóstwa, natomiast cnota ubóstwa powinna nam towarzyszyć na co dzień. Przez

20 Por. Krótki rys biograficzny s. Klary, w: K. K. Staszczak, Drogi Opatrzności Bożej w czasie II wojny światowej dla Sióstr Benedyktynek Misjonarek. Wspomnienia, oprac. A. J. Kalinowska OSB, Olsztyn 1998, s. 9-10 (Seria Biograficzna, 4).

${ }_{21}$ Por. T. Paszkowska, Misterium konsekracji osób w perspektywie Soboru Watykańskiego II, Lublin 2005, s. 211.

22 Zob. Zapiski z rekolekcji 2 lipiec 1970 r., ABMO, tk. P 12/3.

23 Zob. T. Paszkowska, Misterium konsekracji osób..., dz. cyt., s. 210. 
wyrzeczenie się tego, co nie jest nam konieczne do życia lub pracy. To nic, że inni mają więcej, ja muszę postępować śladami Reguły benedyktyńskiej" ${ }^{24}$. Siostra Klara, naśladując ubóstwo Jezusa, który wszystko otrzymał od Ojca, i z wielką miłością wszystko Mu oddając (por. J 17, 7.10), całkowicie zawierzyła się miłości Boga, który ją wezwał do swej wyłącznej służby i Jemu się poświęciła w wyłącznym oddaniu. Charakterystyczną cechą s. Klary na drodze radykalizmu ewangelicznego, realizującego się w ślubie ubóstwa była bezinteresowna służba drugiemu człowiekowi i szczególna troska o tych, którym Syn Boży okazywał swoje szczególne zainteresowanie. Chodzi o ludzi ubogich, opuszczonych, skrzywdzonych i często bezradnych. „Właśnie ta służba pozwala dostrzec szczególnie wyraziście, że życie konsekrowane objawia jedność przykazania miłości - nierozerwalną więź między miłością Boga a miłością bliźniego"25.

Ślub ubóstwa pozwalał s. Klarze rozumieć ludzi ubogich i świadczył o tym, że jej szczęście nie płynie z posiadania rzeczy materialnych, lecz z faktu, że jest własnością Boga ${ }^{26}$. Charyzmat i związane z nimi formy aktywności s. Klary były sposobem ukazywania wielkich dzieł, jakich Bóg dokonywał przez jej osobę i dzieło. Była szczególnym świadkiem prawdy, iż Bóg jest największym bogactwem człowieka. „Zbliżał się czas mego powrotu do domu. Zatęskniłam za dziećmi, Siostrami, za Polską! A jednakże żal mi tego ludu! Utrudzony ciężką pracą na polu, w fabryce i w domu, utrudzony kłopotami rodzinnymi, alkoholizmem itp. Jedyną radością starszego pokolenia jest Kościół, modlitwa, Sakramenty św. Zostało jeszcze kilka dni do wyjazdu, które poświęciłam na modlitwę, odwiedzanie chorych, wypożyczanie książek czytelnikom"27.

Z kolei ślub posłuszeństwa to wierne naśladowanie Chrystusa, którego pragnieniem było pełnienie woli Ojca $(\mathrm{J} 4,34)$. Ślubowane posłuszeństwo dla s. Klary nie było rezygnacją z wolności, lecz wyrazem pewności, że prawdziwą wolność daje ufność Bogu. Rozumiała je jako oddanie

\footnotetext{
Zob. Zapiski z rekolekcji 2 lipiec 1970 r., dok. cyt.

Jan Paweł II, adhort. apost. Vita consecrata [dalej: VC], 5.

Por. J. W. Gogola, Rady ewangeliczne, Kraków 1999, s. 235.

K. K. Staszczak, Zapiski z podróży do Murafy w ZSSR 22 lipca 1971 r., ABMO, tk. P 12/3.
} 
swojej woli przełożonemu z miłości do Boga, a jego wartość upatrywała $\mathrm{w}$ realizowaniu go w duchu ofiary ${ }^{28}$. Idea ta wypływała również z ducha benedyktyńskiego, dla którego posłuszeństwo jest fundamentalną zasadą życia duchowego. Z Reguły św. Benedykta s. Klara zaczerpnęła i przyjęła posłuszeństwo jako drogę do osiągnięcia pełnej dojrzałości ${ }^{29}$. skoro Chrystus był posłuszny aż do śmierci, to i dla s. Klary nie było innej drogi. Nie tracąc nic ze swej wolności, pomimo cierpień i trudności, wsłuchiwała się w wolę Bożą i była jej konsekwentnie posłuszna. „Mimo dachu nad głową przygnębiała nas niepewność jutra. Nikt tutaj [w Kruszynie] nami się nie interesował, nie byłyśmy nikomu potrzebne. Martwiłyśmy się losami naszego Zgromadzenia w Łucku. [...] dnia 10 sierpnia 1944 roku po Mszy świętej ks. Proboszcz nas zatrzymał w zakrystii i zaproponował, byśmy przeniosły się na plebanię... [stamtąd] miałyśmy piękny widok przez okno na mieszkanie Króla królów, który w swoim życiu przeżył sam głód, chłód i wygnanie. I nadal przeżywa głód miłości naszej ku Niemu i bliźnim naszym. Chłód i obojętność wobec Boga, Jego przykazań i Kościoła świętego. Wygnanie z ziemi ojczystej i ciągłe wygnanie Go z duszy ludzkiej przez grzech ${ }^{30 "}$. Nawet w takiej sytuacji s. Klara pozostawała wierna powołaniu. Zdając się na wolę Bożą, z radością i ufnością dorastała do posłuszeństwa przez całe życie. Modliła się o wytrwałość na własnej drodze. Jej modlitwa była też przejawem zależności od Boga Ojca. Ślubowanie i realizowanie rad ewangelicznych miało na celu umocnienie s. Klary w miłości Boga ponad wszystko i jednocześnie ukazanie dóbr niebieskich. Posłuszeństwo była dla niej zawsze twórczym działaniem: „na polecenie Matki Tekli Domańskiej wyjechałam do Puław, by zorganizować tam dom dziecka. Pracę w Puławach rozpoczęłam w piątek 21 listopada 1945 roku w święto Ofiarowania Matki Bożej. Rzeczywiście to było dla mnie ofiarowanie, gdyż bardzo nie chciałam pracować w sierocińcu. Ale taka była wola Boża i wola przełożonych. Błogosławię jednak ten dzień i Panu Bogu dziękuję..." ${ }^{31}$. Siostra Klara wie-

28 Por. Zapiski z rekolekcji 2 lipiec 1970 r., dok. cyt.

29 Por. L. Knabit, Tajemnice zakonu, Kraków 2008, s. 38.

30 Zob. K. K. Staszczak, Drogi Opatrzności Bożej..., dz. cyt., s. 57, 63.

31 K. K. Staszczak, Drogi Opatrzności Bożej..., dz. cyt., s. 83. 
rzyła, że istotą posłuszeństwa ślubowanego Panu jest poddanie się Jego woli wyrażonej w konstytucjach, Regule, a objawionej przez prawowitych przełożonych. Konieczny jest przy tym duch wiary, który stanowi fundament posłuszeństwa i w ogóle sens życia w klasztorze. Bez wiary rozumienie posłuszeństwa, czystości i ubóstwa jest praktycznie niemożliwe, bo sprowadza się ono wówczas do bezsensownego, mechanicznego i zewnętrznego wypełniania poleceń. Zawsze przez wiarę angażowała się w ślub posłuszeństwa nie tylko w sposób zewnętrzny, ale i wewnętrzny, poprzez rozum i wolę. Nie oznacza to, że posłuszeństwo zawsze przychodziło jej łatwo, musiała hartować swą wolę, by widzieć Boga w człowieku i uznać, że ten konkretny człowiek zastępuje Boga na ziemi i objawia Jego wolę. Nigdy też nie rozumiała posłuszeństwa jako bezmyślności, lecz pojmowała je jako twórcze działanie: „ślub posłuszeństwa jest to rozumne oddanie woli swojej przełożonemu z miłości ku Bogu"32. Można uznać, że s. Klara bardzo precyzyjnie określała tę radę ewangeliczną. Potrafiła ukazać sens złożonych ślubów, ze szczególnym akcentem na ślub posłuszeństwa, i własną postawą zachęcała siostry do jego praktykowania, trwania w nim i ukochania go jako formy odpowiedzi na dar powołania i wybrania.

Realizacja ślubu czystości, ubóstwa i posłuszeństwa w ramach wspólnoty zakonnej stanowi potwierdzenie, że s. Klara, wierna Bogu, potrafiła żyć w harmonii i przyjaźni z innymi ludźmi. Potwierdza to również dokument o życiu konsekrowanym św. Jana Pawła II Vita Consecrata: „Kościół objawia w pełni swoje wielorakie bogactwo duchowe, kiedy odrzucając wszelką dyskryminację, przyjmuje jako prawdziwe błogosławieństwo dary Boże, udzielone zarówno mężczyznom, jak i kobietom, i właściwie ceni równą godność wszystkich" (57).

Analizując realizację ślubów zakonnych w życiu siostry Klary, dostrzegamy, że logika powołania wynika z Bożej logiki, czyli z bezinteresownej miłości. Dlatego ostatecznym sensem jest nie tyle skuteczność działania, ile bezinteresowność daru. W osobie s. Klary Klementyny Staszczak obie te rzeczywistości znalazły swoje dopełnienie. Pozostała czytelnym znakiem bezinteresownego daru z samej siebie. Zachwycona pięknem

32 Zob. Zapiski z rekolekcji 2 lipiec 1970 r., dok. cyt. 
i dobrocią Zbawiciela stała się odpowiedzią miłości na dar współudziału w Jego boskiej misji w świecie ${ }^{33}$. Odpowiedź na taki dar wymagała również stanowczego dążenia do świętości.

\section{Heroizm ofiarowania w życiu s. Klary Staszczak}

Świętość i heroizm ofiarowania są terminami sobie bliskimi. Od soboru watykańskiego II mówi się o powszechnym powołaniu do świętości. Mając to na uwadze, możemy stwierdzić, że chociaż świętość i heroizm nie są terminami pokrewnymi, to z pewnością heroizm w jakimś sensie jest doświadczalnym aspektem świętości. W Regule św. Benedykta czytamy: „Gdyśmy zapytali Pana, kto może zamieszkać w Jego Przybytku, usłyszeliśmy w odpowiedzi, co należy czynić, by w nim zamieszkać" ${ }^{34}$. W tym kontekście staje się zrozumiałe doświadczenie heroicznej realizacji ślubów zakonnych s. Klary Staszczak. Nie można mówić o świętości danej osoby bez odniesienia do sposobu jej realizacji w codziennym życiu. Podobnie jak świętość, heroizm jest jeden w swej istocie, a różnorodny $\mathrm{w}$ formie wyrazu. Jednak jako doświadczenie duchowe można go rozumieć jedynie w powiązaniu z misterium Chrystusa, bo tylko On może obdarować tym szczególnym doświadczeniem heroizmu człowieka gotowego przyjąć ten dar. Bez wątpienia doświadczenie całkowitego oddania odsłonięte jest w Jezusie Chrystusie i uobecnione w sakramentach Kościoła. Siostra Klara wiedziała, że kto kieruje swe życie ku Bogu, nie potrzebuje się obawiać, że przyjmuje na siebie ciężar nie do udźwignięcia. s. Klara starała się wypełniać przyjęte zobowiązania w sposób heroiczny.

Podstawę heroizmu ofiarowania $\mathrm{w}$ życiu radami ewangelicznymi w klasztorach monastycznych stanowi Reguła św. Benedykta, zredagowana około 540 roku. Według Reguły należy wyrzekać się samego siebie, by iść za Chrystusem. Najpełniejszy wyraz, zgodnie z duchem Reguły, to oddanie w życiu s. Klary uzyskało w bezgranicznym posłuszeństwie i najwyższym stopniu pokory. Było więc dojrzałym wyrazem

33 Por. VC 104.

34 Św. Benedykt, Reguła, Prolog. 
doświadczenia duchowego, czyli spotkaniem z Bogiem w wierze, nadziei i miłości ${ }^{35}$. Tego rodzaju doświadczenie zawsze dotyczy osobowego kontaktu z Bogiem. Siostra Klara była uległa, dyspozycyjna i otwarta na Boże wezwanie i Jego działanie.

Po kilkuletniej korespondencji utrzymywanej z ks. Antonim Chomickim ${ }^{36}$ s. Klara w 1971 roku zdecydowała się pojechać na Ukrainę. Decyzja o wyjeździe była trudna. $\mathrm{W}$ jednym $\mathrm{z}$ listów do przełożonej s. Klara pytała, czy pomysł wyjazdu na Wschód nie jest jedynie utopią ${ }^{37}$. Liczyła już 66 lat życia, była chora, szczególnie odczuwała dolegliwości związane z sercem. Dużo się modliła o poznanie woli Bożej, czy wyruszać w nieznane, które wydawało się równie pociągające, jak i niebezpieczne. Po załatwieniu formalności z władzami państwowymi razem z ks. Stefanem Soszką i znajomą - Czesławą Kraus 22 lipca 1971 roku wyruszyła na Wschód. Droga wiodła przez Lublin, Przemyśl do Mościsk. Polska kontrola graniczna tylko sprawdziła dokumenty, natomiast po stronie radzieckiej czekała ją drobiazgowa kontrola osobista i kontrola bagażu ${ }^{38}$. „Nie znaleziono nic ukrytego - wspomina s. Klara - gdyż nic nie ukrywałam, Pismo św. Tysiąclecia i inne książki religijne zostały mi zabrane" ${ }^{39}$. Po kolejnych przesiadkach dotarła wreszcie do stacji Jaroszyka, gdzie czekał kierowca, który miał zawieźć siostrę do Murafy. „Był śliczny lipcowy poranek, rosa perlista błyszczała w słońcu, powietrze czyste i bezchmurne niebo. Podole! - pełne historycznych wspomnień, męczenników, wiary i polskości, wodzów i zdrajców oraz osnowa dla dumek i powieści" ${ }^{40}$. Powitana przez ks. Chomickiego, pierwsze kroki skierowała do podominikańskiego kościoła, który był zadbany i dobrze

35 Zob. J.W. Gogola, Mistycy i mistyka Karmelu, Kraków 2007, s. 19.

36 Antoni Chomicki, ps. Roch urodził się 9 kwietnia 1909 roku we wsi Samułki Duże; zmarł 13 maja 1993 roku w Murafie. Po II wojnie światowej ks. Antoni był jedynym duszpasterzem katolickim na terenie ok. 140 tys. km2, obsługiwał m.in. Kijów, Winnicę, Bar, Szarogród, Kamieniec Podolski i inne. Ks. Chomicki położył ogromne zasługi dla przetrwania Kościoła katolickiego na Ukrainie.

${ }_{37}$ List od przełożonej generalnej z 4.01.1972 r., ABMO P12/1/16.

38 M. Wolska, Zaangażowanie Sióstr Benedyktynek Misjonarek na rzecz kościoła katolickiego na Ukrainie, dz. cyt.

39 K. Staszczak, Zapiski z podróży do Murafy USRR dn. 22 lipca 1971 r., dok. cyt.

$40 \quad$ K. Staszczak, Zapiski z podróży do Murafy USRR dn. 22 lipca 1971 r., dok. cyt. 
utrzymany. Zarówno wewnątrz, jak i na zewnątrz czuć było troskliwą rękę proboszcza i zaangażowanie parafian, by dom Boży był utrzymany w należytym porządku. Siostra zapisała wrażenia z pierwszej mszy świętej: „Wejście kapłana poprzedzone przez 8 ministrantów, mężczyzn dorosłych i nawet niektórzy w starszym wieku ${ }^{41}$, w pelerynach czerwonych, dwóch kleryków i ks. Infułat w białym ślicznie złotem naszywanym ornacie. Odsłonięcie obrazu przy organach i pieśni Witaj, święta. Mimo że dzień powszedni, ludzi dużo. Kobiety w białych lub jasnych chustkach, dzieci przy balustradzie, mężczyźni po lewej stronie. Msza św. śpiewana, śpiewają wszyscy po polsku, głosy piękne, kobiety soprany wysokie, męskie basy, tenory, dzieci śpiewają również. Coś chwyta z gardło i łzy radości spływają, że na tej ziemi mimo trudności, zsyłek zachowała się wiara i miłość Boga. Wszyscy równo recytują. Śpiew Ojcze nasz jakiś rzewny ze swoistym akcentem wschodnim. Do Komunii przystępują prawie wszyscy. Kapłanowi asystują przy rozdawaniu Komunii św. klerycy, jeden z tacą, drugi ze świecą. Po Komunii św. modlitwy dziękczynne odmawia z chóru organista" ${ }^{42}$.

Zauważamy ogromne przywiązanie s. Klary do przyjmowanych i celebrowanych sakramentów. Świadczy to o owocnym przeżywaniu sakramentu chrztu, który otwierał i uwrażliwiał ją na doświadczenie Boga we własnym życiu. Była przekonana, że wolą Bożą jest nieustanne trwanie w Jego obecności, a także wykonywanie codziennych obowiązków, stąd nie wahała się nigdy odpowiadać ,tak” na Boże wezwanie. Te dwie rzeczywistości, modlitwa i działanie, nigdy nie wykluczały się w realizowaniu jej powołania. Całym swoim życiem ukazała heroizm oddania siebie innym, ponieważ była mistycznie przynaglana przez miłość Pana. To, co świadkowie jej posługiwania obserwowali u schyłku jej życia, nosiło na sobie ślad wszystkich środowisk, w których wzrastała. Bez wątpienia głęboko heroiczna realizacja złożonych ślubów była jej udziałem, bo przecież owoce życia, jakie pozostawiła, są tego wystarczającym

${ }^{41}$ Władze zabraniały, by dzieci i młodzież przed ukończeniem 18 roku życia brały udział w służbie liturgicznej. Uważano to za agitację i karano tych, którzy nie stosowali się do zarządzeń. Zdarzało się nawet, że rodzicom, którzy prowadzili dzieci do kościoła, odbierano prawo do ich wychowania i umieszczano je w domach dziecka.

42 K. Staszczak, Zapiski z podróży do Murafy USRR dn. 22 lipca 1971 r., dok. cyt. 
dowodem i potwierdzeniem, że „wszystko jest możliwe dla tego, kto wierzy" (Mk 9, 23).

Siostra Klara zmarła w Barze 19 czerwca 1991 roku. Jej pogrzeb stał się manifestacją wiary odradzającego się Kościoła. Księża pracujący na Podolu odprawiali w tym czasie swe doroczne rekolekcje w Barze, które głosił o. Albert Krąipiec OP${ }^{43}$. Mszę świętą pogrzebową celebrowało dwudziestu pięciu prezbiterów pod przewodnictwem bp. Jana Olszańskiego ${ }^{44}$. Był to jakby uśmiech Boga nad tą, która wychowała kilku kapłanów, która całe życie za kapłanów się modliła, ofiarując swe cierpienia, i służyła im pomocą. Trumnę otoczyły też siostry benedyktynki misjonarki z podolskiej ziemi, ubrane w habity - jej duchowe córki. Barski kościół rozbrzmiewał mocnym, pięknym śpiewem licznie zebranego, umiłowanego przez nią wiernego ludu Bożego ${ }^{45}$. Siostra Klara $\mathrm{w}$ dobrych zawodach wystąpiła, bieg ukończyła, wiary ustrzegła (por. $2 \mathrm{Tm} 4,7)$. Nie można jej odmówić inicjatywy apostolskiej ani odwagi graniczącej z heroizmem, uporu, który na każdym etapie dawał pozytywne wyniki. Kochać Boga jako Oblubieńca można jedynie Jego własną miłością. Stąd odmowa otwarcia serca na Jego wszechogarniającą miłość w jakimkolwiek z omówionych wyżej wymiarów życia siostry Klary uniemożliwiałaby prawdziwe zjednoczenie w miłości. Właśnie w tej perspektywie zjednoczenie s. Klary z Bogiem przez miłość znajduje swoje właściwe i niedające się niczym zastąpić miejsce, i zdecydowanie zawiera

${ }^{43}$ Urodził się 25.05.1921 w Berezowicy Małej na Podolu. W 1939 roku ukończył w Tarnopolu Gimnazjum im. Wincentego Pola i w tymże roku wstąpił do zakonu dominikanów w Krakowie, gdzie odbył studia filozoficzne i teologiczne, zwieńczone w 1946 roku doktoratem, którego promotorem był o. Jacek Woroniecki. Pracę na KUL rozpoczął w 1951 roku, na działającym zaledwie od 1946 roku Wydziale Filozofii. Dwukrotnie pełnił funkcję dziekana Wydziału Filozofii Chrześcijańskiej KUL (1958-1961 i 1969-1970). Od 1 października 1970 roku sprawował urząd rektora (przez pięć kadencji - do 1983 roku). W swojej twórczości naukowej zespala filozofię starożytną ze średniowieczną, koncentrując się przede wszystkim na teorii bytu Arystotelesa i św. Tomasza z Akwinu (zob.:http://www.kul. pl/o-mieczyslaw-albert-krapiec-op,art_9087.html, 14.02.2012).

44 Urodził się 14 stycznia 1919 w Huciskach koło Tarnopola, zm. 23 lutego 2003 w Kamieńcu Podolskim - polski rzymskokatolicki biskup, ordynariusz diecezji kamieniecko-podolskiej, marianin.

45 Zob. M. Wolska, Zaangażowanie Sióstr benedyktynek misjonarek na rzecz kościoła katolickiego na Ukrainie, dz. cyt. 
się w przypomnianym przez Sobór Watykański II powszechnym powołaniu wszystkich ludzi do świętości ${ }^{46}$. Zjednoczenie z Bogiem owocowało doskonałą z jej strony miłością Boga, siebie samej i bliźniego, co bez wątpienia stanowiło najważniejszy przyczynek w budowaniu w jej współczesnym świecie cywilizacji miłości.

\section{Zakończenie}

„Przepasawszy więc biodra wiarą i pełnieniem dobrych uczynków, podążajmy ścieżkami Pana za przewodem Ewangelii, abyśmy zasłużyli na oglądanie Tego, który nas wezwał do swego Królestwa. Jeśli zaś pragniemy zamieszkać w Przybytku Jego Królestwa, musimy biec drogą dobrych uczynków, gdyż inną tam się nie dochodzi ${ }^{47}$ ”. Życie siostry Klary Staszczak na ziemi było drogą do „domu Ojca”. Święty Benedykt mówi, że trzeba nią iść, „przepasawszy biodra wiarą i pełnieniem dobrych uczynków". Przepasane biodra są znakiem gotowości, znakiem zasadniczej postawy. Aby prawdziwie iść drogą „wiary i dobrych uczynków”, trzeba tego pragnąć i jednocześnie być otwartym na Boże wskazania, pozwolić się Bogu prowadzić, o czym św. Benedykt mówi obszernie w dalszej części Reguły, w szczególności gdy pisze o posłuszeństwie. Siostra Klara Staszczak ,przykładem swojego życia, heroicznym poświęceniem zdołała przekazać siostrom [na Ukrainie] duchowość św. Benedykta - szczególne umiłowanie Chrystusa w liturgii, w Piśmie świętym, w cierpiących braciach i siostrach. W jej życiu odzwierciedlił się paschalny charakter duchowości benedyktyńskiej - naśladowanie Chrystusa w jego wyrzeczeniu i pokorze. Jako wierna córka Matki Założycielki Jadwigi Kuleszy, którą znała osobiście - s. Klara szczególną czcią otaczała Najświętsze Serce Jezusa i kult ten przekazywała siostrom ${ }^{48 "}$.

46 Por. Sobór Watykański II, konst. Lumen gentium, 39.

${ }_{47}$ Św. Benedykt, Reguła, Prolog.

${ }^{48}$ F. J. Kowalska, Duchowość benedyktyńska realizowana przez Siostry Benedyktynki Misjonarki w Delegaturze Zgromadzenia na Ukrainie, Warszawa 1999, ABMO, mgr, s. 14; tekst i przypis za: E. Piaścik, Zgromadzenie Sióstr Benedyktynek Misjonarek na Ukrainie w latach 1977-1991, Lublin 2008, s. 92. 
Podstawą i źródłem wszelkich działań siostry Klary było misterium zbawcze w pełni objawione w Chrystusie i dostępne w Kościele w sakramentalnym spotkaniu z Bogiem, przyswajalne dzięki postawie wiary i miłości. To ostatecznie przesądza sprawę o heroicznym charakterze realizacji przez Nią konsekracji zakonnej, będącej owocem zbawczego działania Boga w Chrystusie mocą Ducha Świętego.

Jej postać zasługuje na poznanie, a jej życie na wnikliwe, naukowe opracowanie. Bez wątpienia heroiczna realizacja czystości, ubóstwa i posłuszeństwa, będąca przedmiotem niniejszego artykułu, znalazłaby wówczas pełniejszy kształt i wyłoniłyby się nowe perspektywy opracowania podjętego zagadnienia. 


\section{Summary}

\section{Siostra Klara Staszczak (1905-1991) jako przykład heroicznej realizacji konsekracji zakonnej}

Klementyna Staszczak - s. Maria Klara urodziła się 6 listopada 1905 roku w Żdżarach w powiecie włodzimierskim. W 1922 roku wstąpiła do Zgromadzenia Sióstr Benedyktynek Misjonarek. Pierwsze śluby zakonne złożyła 15 sierpnia 1924 roku w Kowlu, śluby wieczyste - 15 sierpnia 1931 roku w Łucku. Na Ukrainie przebywała w latach 1924-1943; 1971-1986; 1989-1991. Siostra Klara Staszczak szczególnie umiłowała Kresy Wschodnie, którym oddała całe swe serce. Heroizm realizacji konsekracji zakonnej s. Klary ukształtowała wiara, przeżywana w codziennej modlitwie oraz podejmowanym trudzie kroczenia drogą przykazań i Ewangelii. Heroiczne wręcz pokonywanie trudności na drodze odnawiającego się zgromadzenia na Kresach Wschodnich pokazuje silne zjednoczenie s. Klary z Chrystusem. Dzięki całkowitemu oddaniu siebie Jezusowi jako Panu i Zbawicielowi oraz rzetelnej pracy w duchu Reguły św. Benedykta, s. Klarze udało się na nowo zaszczepić i rozwinąć działalność Zgromadzenia Sióstr Benedyktynek Misjonarek na Ukrainie. Całe jej życie było służbą Bogu, Kościołowi, zgromadzeniu i drugiemu człowiekowi, szczególnie temu najbardziej potrzebującemu ewangelicznej troski. Zmarła 19 czerwca 1991 roku w Barze na Podolu, tam też została pochowana. Do dnia dzisiejszego siostry na Ukrainie kontynuują spuściznę duchową matki założycielki, którą s. Klara po 60 latach nieobecności sióstr na Kresach Wschodnich zaszczepiła na nowo na tej ziemi.

Słowa kluczowe: powołanie, duchowość benedyktyńska, śluby zakonne czystości, ubóstwa i posłuszeństwa, heroiczna realizacja konsekracji

\section{Sister Klara Staszczak (1905-1991) as an example heroic realization of religious consecration}

Klementyna Staszczak - sister Maria Klara was born in Zdzarach in wlodzimierski county on November $6^{\text {th }} 1905$. In 1922 she joined the Congregation of the Sisters of Benedictine Missionaries. She took her initial vows of chastity on August 15, 1924 in Kowal and her everlasting vows on August 15, 1931 in Luck. From 1924 to 1943 , from 1971 to 1986, and from 1989 to 1991 she lived in Ukraine. Sister Klara Staszczak particularly loved the region of Estern Boderlands to which she was wholeheartedly devoted. Her faith, life in her everyday prayer, as well as her commitment to overcoming the hardships required when walking according to the Gospel and God's commandments, shaped her heroism in realization of the covenant's consecration. Her ability to heroically overcome the difficulties arising on the way of the renewing of the Congregation on the Estern Boderlands, show 
how strongly sister Klara was unified with Christ. Thanks to her absolute devotion to Jesus as her Lord and Savior and her bona fide work, rooted in the spirit of the rules of St. Benedict, sister Klara was successful in initiating and developing the activity of the Congregation of the Sisters of Benedictine Missionaries in Ukraine. Her whole life was devoted to serve God, Church, Congregation, and to other men, especially those who were in most need of the Gospel care. She died on June $6^{\text {th }} 1991$ in Bar in Podole region and was buried there.

To this day sisters in Ukraine are continuing the spiritual heritage of the Founding Mother, which sister Klara, after 60 years of nun's absence, was able to re-establish in the Estern Boderlands region.

Keywords: vocation, Benedictine spirituality, vows of chastity, poverty and obedience, realization of heroic consecration

\section{Bibliografia}

Archiwum Zgromadzenia Sióstr Benedyktynek Misjonarek w Otwocku.

Błogosławieni, którzy w umieraja w Panu. Nekrologia Sióstr Benedyktynek Misjonarek i szczególnych dobroczyńców Zgromadzenia (1924-1999), praca zbiorowa pod red. J. Kalinowskiej, Olsztyn 2000.

Gogola J. W., Mistycy i mistyka Karmelu, Kraków 2007.

Gogola J. W., Rady ewangeliczne, Kraków 1999.

Gogola J. W., Teologia komunii z Bogiem, Kraków 2003.

Jagłowski A., Historia Zgromadzenia Sióstr Misjonarek św. O. Benedykta, Olsztyn 1955, Archiwum Zgromadzenia Sióstr Benedyktynek Misjonarek w Otwocku, mps.

Jan Paweł II, Adhortacja Vita Consecrata, Rzym 1996.

Jan Paweł II, Wielki Jubileusz wezwaniem dla rodzin. Katecheza środowa, 29.12.1999, http://www.opoka.org.pl/biblioteka/W/WP/jan_pawel_ii/audiencje/ ag_29121999.html (07.02.2013).

Katechizm Kościoła Katolickiego, Poznań 1994.

Knabit L., Tajemnice zakonu, Kraków 2008.

Kowalska F. J., Duchowość benedyktyńska realizowana przez Siostry Benedyktynki Misjonarki w Delegaturze Zgromadzenia na Ukrainie, Warszawa 1999.

Kycia L., O. Mieczysław Albert Krapiec, www.kul.pl/o-mieczyslaw-albert-krapiec-op,art_9087.html (15.01.2013).

List od przełożonej generalnej z 4.01.1972 r., Archiwum Zgromadzenia Sióstr Benedyktynek Misjonarek w Otwocku P12/2.

Misiurek J., Modlitwa, medytacja, kontemplacja, mistyka. Dzieje problematyki, Lublin 2011.

Paszkowska T., Misterium konsekracji osób w perspektywie Soboru Watykańskiego II, Lublin 2005.

Piaścik E., Zgromadzenie Sióstr Benedyktynek Misjonarek na Ukrainie w latach 1977-1991, Lublin 2008. 
Pismo Święte Starego i Nowego Testamentu, Biblia Tysiąclecia, Poznań 2008.

Rękopisy własne s. Klary Staszczak, Archiwum Zgromadzenia Sióstr Benedyktynek Misjonarek w Otwocku P 12/3.

Sobór Watykański II, Konstytucje, dekrety, deklaracje, Poznań 2002.

Staszczak K., Drogi Opatrzności Bożej w czasie II wojny światowej dla Sióstr Benedyktynek Misjonarek. Wspomnienia, oprac. A.J. Kalinowska OSB, Olsztyn 1998 (Seria Biograficzna, 4).

Staszczak K., Zapiski z podróży do Murafy USRR dn. 22 lipca 1971 r., Archiwum Zgromadzenia Sióstr Benedyktynek Misjonarek w Otwocku P12/3/1 rkps.

św. Benedykt, Reguła, Tyniec 1979.

Wolska M., Zaangażowanie Sióstr Benedyktynek Misjonarek na rzecz Kościoła katolickiego na Ukrainie. Referat wygłoszony podczas Międzynarodowej Sesji Naukowej Zaangażowanie duchowieństwa polskiego na rzecz Kościoła katolickiego na Wschodzie (Ukraina), Lublin, 21-22.10.2005.

Wspomnienia Wojtka Dudzika w: Dokumenty, życiorysy, podróże, Listy s. Klary, Archiwum Zgromadzenia Sióstr Benedyktynek Misjonarek w Otwocku, rkps, tk. P 12/1.

www.katolicy.eu [brak autora] podstrona: Polscy księża represjonowani w bolszewickiej Rosji w latach 1917-1991, Abp Ignacy Dub-Dubowski, ordynariusz diecezji łucko-żytomierskiej (12.10.2012).

www.katolicy.eu [brak autora] podstrona: Polscy księża represjonowani w bolszewickiej Rosji w latach 1917-1991, Ks. Feliks Sznarbachowski, działacz narodowy (12.10.2012).

www.katolicy.eu [brak autora] podstrona: Polscy księża represjonowani w bolszewickiej Rosji w latach 1917-1991, Bp. Jan Olszański, duszpasterz Polaków w ZSRR (12.10.2012).

Życiorys s. Klementyny Klary Staszczak, w: Dokumenty, życiorysy, podróże, Listy s. Klary, Archiwum Zgromadzenia Sióstr Benedyktynek Misjonarek w Otwocku, rkps, tk. P $12 / 1$. 